\title{
Makroekonomik Kırılganlığın Ölçülmesi: Balkan Ülkeleri ve Türkiye İçin Karşılaştırmalı Bir Analiz
}

\author{
Nevzat BALIKÇIOĞLU
}

$\ddot{O} z$

Ülkelerin makroekonomik göstergelerini iç ve diş konjonktürdeki gelişmelerden olumsuz yönde etkileyen ve ülke ekonomilerinde risk ve belirsizliği artırarak istikrarsızlığa yol açan sorunlar şeklinde tanımlanan kırılganlık kavramı, son dönemlerde dünya ekonomisinde yaşanan istikrarsızlıklar ve krizler nedeniyle ön plana çıkmaya başlamıştır. Bu çalışmada 2007-2017 dönemi için Türkiye ve Balkan ülkelerinin makroekonomik kırılganlığ1 karşılaştırmalı olarak analizi amaçlanmaktadır. Bu çerçeveden hareketle makroekonomik kırılganlıkla ilgili literatür incelenmesi yapılmış, Türkiye ve Balkan ülkelerinin çeşitli temel ekonomik göstergeler üzerinden performansları analiz edilmiştir. Analizde makroekonomik kırılganlığı ölçmek için mali kırılganlık (bütçe dengesi/GSYH, kamu borcu/GSYH), finansal kırılganlık (özel sektöre yurtiçi kredilerin GSYH oranı, yıllık kredi büyüme oranları) ve dış kırılganlık (cari denge/GSYH, döviz rezervi/GSYH) olmak üzere altı temel değişkenden faydalanılmışır. Yapılan karşılaştırmada, Türkiye ekonomisinde kırılganlı̆̆a yol açan unsurların cari denge/GSYH, yıllık kredi büyüme oranı ve döviz rezervi/GSYH olduğu tespit edilirken, Bulgaristan döviz rezervi/GSYH, bütçe dengesi/GSYH ve kamu borcu/GSYH'de, Kosova bütçe dengesi/GSYH, yurtiçi kredi büyümesinde kırılganlı̆ğ en az olan ülkeler olmuştur. Yunanistan cari denge/GSYH, döviz rezervi/GSYH, bütçe dengesi/GSYH, kamu borcu/GSYH ve yurtiçi kredi büyümesindeki kırılganlıkları ile incelenen ülkeler içerisinde en kırılgan ülke konumundadır.

Anabtar Kelimeler: Kırılganlık, Makroekonomik kırılganlık, Türkiye, Balkan ülkeleri

\section{Macro-Economic Fragility Measurement: A Comparative Analysis for Balkan Countries and Turkey}

\section{Abstract}

The concept of fragility, which adversely affects the macroeconomic indicators of the countries in the domestic and foreign conjuncture developments and which leads to instability by increasing risk and uncertainty in the economies of the countries, has started to come to the fore due to the instability and crises experienced in the world economy in recent times. In this study, it is aimed to analyze the macroeconomic vulnerability of Turkey and Balkan countries comparatively for 2007-2017 periods. From this perspective, the literature on macroeconomic vulnerability has been examined and performances of Turkey and Balkan countries have been analyzed through various basic economic indicators. In the analysis, six key variables were used to measure macroeconomic vulnerability: fiscal vulnerability (budget balance/GDP, public debt/GDP), financial vulnerability (the ratio of domestic loans to the private sector, annual credit growth rates) and external vulnerability (current balance/GDP, and foreign currency reserve/GDP). It was determined in the comparison that the factors that led to fragility in the Turkish economy were the current balance/GDP, annual credit growth rate and foreign currency reserve/GDP, while Kosovo has the least fragility in the budget balance / GDP, and domestic credit growth, and Bulgaria has the least fragility in foreign exchange reserve/GDP, budget balance/GDP and public debt/GDP ranked first. Greece is the most vulnerable country among the countries surveyed with its current balance/GDP, foreign exchange reserve/GDP, budget balance/GDP, public debt/GDP and fragility in domestic credit growth.

Key Words: Fragility, Macroeconomic fragility, Turkey, Balkan countries

\section{Atıf İçin / Please Cite As:}

Balıkçığlu, N. (2020). Makroekonomik kırılganlığın ölçülmesi: Balkan ülkeleri ve Türkiye için karşılaştırmalı bir analiz. Manas Sosyal Arastırmalar Dergisi, 9(3), 1573-1588.

Geliş Tarihi / Received Date: 09.07.2019

Kabul Tarihi / Accepted Date: 28.01.2020

\footnotetext{
${ }^{1}$ Dr. Öğr. Üyesi - Sivas Cumhuriyet Üniversitesi İktisadi ve İdari Bilimler Fakültesi, balikcioglu@cumhuriyet.edu.tr ORCID: 0000-0002-8642-9013
} 


\section{Giriş}

Makroekonomik kırılganlık kavramı, Morgan Stanley'in (2013) ekonomi raporunda yatırım bankası tarafindan cari açık/GSYH oranı ş̧ı̆ıında, küresel sermaye akımlarına karşı en kırılgan yapıya sahip ülkeleri ("Kırılgan Beşli”) tanımlamak için kullanılmıştır. Morgan Stanley'in çalışmasını izleyen birçok çalışmada kırılgan beşliye yönelik değerlendirmeler yapılmıştır. Bu çalışmada ise diğerlerinden farklı olarak Balkan ülkeleri ile Türkiye, makroekonomik kırılganlık açısından karşılaştırılmaktadır. Günümüzde makroekonomik kırılganlık, tüm ülke ekonomilerini iç ve dış şoklara karşı kırılgan hale getiren ve krize eğilimli yapılar oluşturan bir sorundur. Makroekonomik kırılganlığın yüksek olduğu ekonomilerde krizler daha şiddetli ve yıkıcı olmaktadır.

Balkan ülkeleri, Türkiye ve Yunanistan hariç 1990’ların başından itibaren merkezi ve planlı ekonomik sistem yerine dışa açık kalkınma modelini uygulamaya koymuşlardır.1990'lı yılların ortalarına kadar bölgede var olan savaş ve siyasi istikrarsızlıklardan ülke ekonomileri olumsuz yönde etkilenmiş, yüksek enflasyon, işsizlik ve düşük oranlarda KBGSYH gibi temel makroekonomik ekonomik sorunlarla karşı karşıya kalmışlardır. Son yıllarda enflasyonu kontrol altına alma konusunda başarılı olsalar da, düşük gelir düzeyi ve yüksek oranlardaki işsizlik sorun olmaya devam etmektedir. Ayrıca 1990'lı yılların başından itibaren serbest piyasa ekonomisi kurallarını uygulamaya koyan Balkan ülkeleri, bu politikaların sağladığı olumlu gelişmelerin yanı sıra, cari işlemler bilançosunda görülen büyük oranlardaki dengesizlikler, işsizlik ve bozulan bütçe dengesi gibi özellikler yönünden iç ve dış şoklara ve spekülasyonlara karşı kırılgan hale gelmişlerdir. Dolayısıyla kırılganlı̆̆ işaret eden göstergeler, ekonomilerin zayıf olduğu alanlanı, krize eğilimli olup olmadığını ya da dış kaynaklı bir krizden etkilenme düzeyini anlamak açısından önemlidir.

Çalışmada yer verilen Balkan ülkeleri, Bosna- Hersek, Bulgaristan, Arnavutluk, Hırvatistan, Yunanistan, Makedonya, Karadağ, Kosova, Romanya ve Sırbistan'dır. 2017 yılı itibariyle bölge içerisinde GSYH en yüksek olan ülke 851 milyar dolar ile Türkiye olurken, bu ülkeyi 212 milyar dolar ile Romanya, 200 milyar dolar ile Yunanistan takip etmektedir. Balkan ülkelerinin dört tanesi (Bulgaristan-RomanyaHirvatistan-Yunanistan) Avrupa Birliği’nin üyesi, Bosna Hersek, Karadağ, Arnavutluk, Kosova, Makedonya ve Sırbistan, Türkiye gibi aday ülke konumundadır. Çalışmada genellikle IMF ve Dünya Bankası verileri kullanılmışıı. Türkiye ve Balkan ülkelerine ilişkin verilerde 2017 yılının dikkate alınmasının nedeni, çalsşma yayına hazırladığında konuyla ilgili 2018 yılı verilerinin kesin olmayan geçici veriler olması nedeniyledir.

\section{Ekonomik Kırılganlık Kavramı ve Kırılganlık Çeşitleri}

İk zamanlarda tehlikeli ve risk konuları kapsamında ele alınan kırılganlık kavramı, sonraki zamanlarda riskin farklı bileşenlerine odaklanan disiplinlerde oldukça farklı anlamlarda kullanılmaya başlanmıştır. Adger (2006, s. 268) kırılganlığ1, "sosyal ve çevresel dönüşümlerin ortaya çıkardığı baskıya maruz kalma sonucu oluşan hassasiyet durumu" olarak tanımlamıştır. Kırılganlğı̆, esneklik ve duyarllık ile birlikte değerlendiren Gheorghe (2001) ise kirllganlığ1, "toplumun, sistemin ve onu meydana getiren çevrenin tehlikelere karşı duyarlılık ve esneklik derecesi” şeklinde tanımlamıştır (Doğantan ve Kozak, 2018, s. 582).

Ekonominin iç ve diş şoklar karşısında dayanıkl olup olmaması, diğer bir ifadeyle ekonomik şoklara karşı hassasiyet şeklinde tammlanan ekonomik. kinlganlık kavram ise ilk olarak Morgan Stanley'in (Ağustos 2013) ekonomi raporunda, yatırım bankası tarafından cari açı/GSYH oranına göre, spekülatif sermaye akımlarına karşı en kırılgan görülen ülkeleri (Kırılgan Beşli) tanımlamak için kullanılmıştır (Mete vd, 2016, s. 290). Özetle kırılganlik; incelenen birimlere göre ve bu birimlerin hangi olaylara karşı risk altında olabileceğine göre farklılık arz etmektedir. Bu nedenle kırılganlığı ölçmek için kullanılan oldukça farklı göstergeler bulunmaktadır (Moody's, 2014, s. 3; IMF, 1998, s. 88). Bunlar bir anlamda kırılganlığın tanımını da vermektedir. Kullanılan farklı göstergelere koşut olarak kırılganlık, ekonomik ve finansal kırılganlık şeklinde ele alınabilmektedir.

\section{Ekonomik Kurılganlık}

Kırlganlık riski taşıyan ekonomik birime göre mikroekonomik ve makroekonomik kır1lganlık olmak üzere ikiye ayrilmıştır (Seth ve Ragab, 2012, s. 2).

\section{Mikroekonomik Kırılganlık}

Hane halkı kırılganlığ olarak da adlandırılan mikroekonomik kırılganlık, bireyleri veya hane halkını esas almakta ve hane halkının kıtlığa, yoksulluğa ve doğal olaylara karşı kırılganlığına değinmektedirler (Andrews ve Flores, 2008, s. 2; Chaudri ve Suryahadi, 2002, s. 4). 
Mikroekonomik kırılganlığa yönelik tanımlamalar, hane halkı kııllganlığının daha çok yoksulluk yönünü esas almışlardır. Bu bağlamda Chaudri ve Suryahadi (2002, s. 4) kırrlganlığı; yoksul olmayan hane halklarının yoksulluk sınırı altına düşmesi, yoksul olanların ise durumunun devam etmesi riski olarak tanımlamışlardır. Seth ve Ragab (2012, s. 1-2) ise, mikroekonomik kırılganlığı; şoklar sonucu hane halkının refahında meydana gelen azalma riski olarak ele almışlardır.

\section{Makroekonomik Kırılganlık}

Makroekonomik kırılganlık, mikroekonomi kırılganlı̆ı̆n aksine bireyleri veya hane halkını değil, bir ülkeyi veya ekonomiyi bir bütün olarak değerlendirmektedir (Karakurt vd., 2015, s. 287).

Makroekonomik kırılganlık, bir ülkenin sahip olduğu özelliklerden, ekonomik yapısından veya uygulanan politikalar neticesinde ortaya çıkabilmektedir. Buna göre makroekonomik kır1lganlık; bir ülkenin ekonomik yapısındaki özellikler nedeniyle kontrolü dışındaki ekonomik güçlere karşı ekonomisinin riskli (açı) hale gelmesidir (Briguglio ve Galea, 2003, s. 3).

Ülke ekonomisini dışa açıklık derecesinde ele alan tanımlamalarda ise makroekonomik kırılganlık, dış ekonomik şoklara karşı hassasiyeti ifade etmek için kullanılmışır (Guillaumont, 1999, s. 4). Dolayısıyla ülkeler dış ekonomik şoklara karşı uyguladıkları politikalar veya yapısal özellikleri nedeniyle kırılgan olabilmektedirler. Nitekim Guillaumont de (2008, s. 2; 2011, s. 1) makroekonomik kırilganlığ1; bir ülkenin ekonomik büyümesinin istikrarsılılklar veya dış ekonomik şoklardan olumsuz yönde etkilenmesi şeklinde tanımlamaktadır. Kırllganlığa makroekonomik açıklık perspektifinden yaklaşan (Briguglio et al, 2009, s. 229)'de kırılganlığı, bir ekonominin dışa açıklık nedeniyle dış şoklara karşı riskli olma durumu olarak tanımlamıstır.

Ayrıca bu iki kırılganlık birbirini tamamlar niteliktedir. Çünkü hane halkının açlığa, doğal olaylara ve yoksulluğa karşı kırılganlığı olan mikroekonomik kırılganlık, aynı zamanda da makroekonomik kırılganlı̆ı̆n bir sonucudur. Şöyle ki, ekonomik büyümede daralma riskini ifade eden makroekonomik kırllganlıktaki bir gelişme, beraberinde hane halkının refahında azalma riskini de getirmektedir (Karakurt vd., 2015, s. 286).

\section{Finansal Kırılganlık}

Finansal kırılganlık kavramı, Fisher ve Keynes'in yatırımların borçlanma ile finanse edilmesinin ekonomik istikrarsızlıklara yol açacağı varsayımına dayanmaktadır. En genel anlamıyla finansal kırılganlık (Boğa, 2017, s. 5) cari işlemler bilançosu, kredi faiz oranları, kısa ve uzun vadeli borçlanmalardaki istikrarsızlıklar neticesinde borç/öz kaynak dengesinin bozulmasıyla ekonominin yeni borçlanma döngüsü içerisine girmesidir. Finansal krizlere karşı öncü göstergeler olan finansal kırılganlık göstergeleri, ekonomik yapının içinde bulunduğu ve ekonomiyi gelecekte ne tür gelişmelerin beklediği hakkında önemli ipuçları vermektedir (Tokucu, 2012, s. 197).

\section{Temel Ekonomik Kırılganlık Göstergeleri}

Temel ekonomik kırılganlık göstergelerini dış kırılganlıklar, mali kırılganlıklar ve finansal kırılganlıklar şeklinde üç gruba ayırabiliriz. Bunlar; (Özyıldız, 2014, s. 1) Dış Kırılganlık Göstergeleri: Cari açık/GSYH, Uluslararası döviz rezervleri/Ülkenin kısa vadeli dış borcu, Uluslararası döviz rezervleri/GSYH, Toplam diş borç/GSYH, Toplam diş borç/Toplam yıllık ihracat, reel kurun aşırı değerlenmesi. Mali Kırılganlık Göstergeleri: Bütçe açı̆̆ı/GSYH, Kamu açığı/GSYH, Toplam kamu borcu/GSYH, Vadesi 12 ay içinde dolan borç/GSYH, Kamu dış borcu/GSYH. Finansal Kırılganlık Göstergeleri: Kredi /mevduat oranı, Yıllık kredi büyümesi, Toplam krediler/GSYH, Finansal sektörün yabancı bankalar borcu/GSYH (Akın, 2017, s. 89).

\section{Literatür İncelemesi}

Literatürde makroekonomik kırılganlık göstergelerini karşılıklı olarak inceleyerek ülkelerin makroekonomik performanslarını ortaya koyan birçok çalışmanın yapıldığı görülmektedir.

Karakurt vd. (2015) çalışmalarında, Türkiye ve Şangay ülkelerinde 2008-2012 dönemine ilişkin makroekonomik kırılganlı̆̆ı ortaya koymak amacıyla beş endeksten faydalanmışlardır. Bunlar; reel efektif döviz kuru, döviz rezervinin GSYH'ye oranı, cari açığın GSYH'ye oranı, yurtiçi kredi büyümesi, kamu borcunun GSYH'ye oranıdır.

Çan ve Dinçsoy (2016) çalışmalarında, Türkiye'nin de içinde olduğu kırılgan beşli ekonomilerinde ekonomik kırılganlığı ölçmek amacıyla çeşitli endekslerden faydalanmışlardır. Bu endeksler; uluslararası 
döviz rezervleri/GSYH oranı, toplam dış borç/GSYH oranı, cari açı/GSYH, uluslararası döviz rezervleri/kısa vadeli dış borç oranı, bütçe açı̆̆ı/GSYH oranı, toplam dış borç/toplam yıllık ihracat oranı, kamu açı̆̆1/GSYH oran1, toplam kamu borcu/GSYH oran1, kamu dış borç/GSYH oran1, kısa vadeli dış borç/GSYH oranı, yıllık kredi büyüme oranı yurtiçi kredi/ GSYH oranı ve Kredi/Mevduat oranıdir.

Bayraktar ve Elüstü (2016) çalısmalarında, Türkiye'nin de içinde olduğu yükselen piyasa ekonomilerinde makroekonomik kırılganlığı ölçmek amacıyla altı endeksten faydalanmışlardır. $\mathrm{Bu}$ endeksler, brüt kamu borcunun GSYH'ye oranı, cari dengenin GSYH'ye oranı, son beş yllda Bankaların özel sektöre kullandırdığı yurt içi kredilerin GSYH'ye oranındaki değişme, son üç yılın enflasyon oranının ortalaması, döviz rezervlerinin GSYH'ye ve toplam dış borcun yıllık ihracata oranıdır.

Akın (2017) çalışmasında, Türkiye ve seçilmiş Balkan ülkelerinde (Bulgaristan, Romanya, Hırvatistan, Yunanistan) makroekonomik kırılganlığı karşılaştırmalı olarak analiz etmiştir. Analizde dış kııllganlık göstergeleri (cari denge/GSYH, döviz rezervi/GSYH), mali kırılganlık göstergeleri (bütçe dengesi/GSYH, kamu borcu/GSYH) ve finansal kırılganlık göstergeleri (yurtiçi kredi büyümesi, kredi/mevduat) olmak üzere altı temel endeksten yararlanmıştır.

\section{Balkan Ülkeleri ve Türkiye'nin Makroekonomik Performans1}

Balkan ülkelerinin ekonomik yapısının incelenmesi amaciyla öncelikle ülkelerin genel ekonomik yapıları ile ilgili kısa bir bilgilendirmenin ardından; nüfus, büyüme, isssizlik, enflasyon, ihracat ve ithalat gibi temel makroekonomik değişkenler IMF, T.C. Ticaret Bakanlı̆̆ı ve Dünya Bankasından elde edilen veriler ışığında 2017 yllı itibariyle incelenmiştir. İlgili değişkene ait Tablo 1'de değerlerinin verilmesinden sonra her ülke için yorumlar aşağıda bulunmaktadır.

Avrupa Birliği’ne 1981 yllında tam üye olan Yunanistan, 2008 yllında başlayan küresel ekonomik krizden ülkenin gerek kamu yönetiminde ve gerekse ekonomisinde uzun yllar devam eden problemlerden dolay1 en çok etkilenen ülkelerden biri olmuştur. Bu süreçte kredi derecelendirme kuruluşları tarafindan kredi notu sürekli düşürülen Yunanistan, gelinen noktada Avrupa'nın en düşük kredi notuna sahip ve borçlarını ifa edemeyen ülkesi görünümündedir. Ekonomik büyümenin ve kamu maliyesinin büyük oranda diş kaynaklarla finanse edildiği ülkede, kamu borç stoku/GSYH oranı \%150'yi aşmış, ülkenin hızla artan borçlanma maliyetleri kamu borç yönetimini sürdürülebilir olmaktan çıkarmıştır. Krizle birlikte ekonomisi sürekli daralan Yunanistan'da işsizlik oranı \% 21'lere ulaşmıştır. 2017'de Bölge ülkeleri içerisinde en büyük KBGSYH (23.000 dolar) sahip olan ülke, Dünya Bankası'nın hazırladığ1 ve 190 ülkedeki yatırım ortamının elverişliliğini ölçen "İş Yapma Kolaylığı" (IYK) adlı raporunda 61. sırada yer alırken, Dünya Ekonomik Forumu'nun (2017-2018) "Küresel Rekabetçilik Endeksi'nde" (KRE) incelenen 140 ülke içerisinde 57. sırada bulunmaktadır.

AB'ne potansiyel aday ülke statüsü 2003 yllında verilmiş olan Sırbistan $77.00 \mathrm{~km}$ ve 7 milyon nüfusa sahip bir ülkedir. Sırbistan'ın en önemli ekonomik sorunları \%14,1 olan işsizlik, kamu harcamalarının önemli bir kısmının ücret, emeklilik ve işsizliğe ayrılması, sürekli artan kamu borçlanmaları, yabanc1 yatırımların yetersizliği ve artan dış borçlardır. 2017 verilerine göre bölgede Türkiye'den sonra en yüksek enflasyon oranına $(\% 3,1)$ sahip olan Sırbistan, ekonomisini dönüştürmekte nispi olarak geç kalmıştır (Güngör, 2016, s. 278-279). 
Tablo 1. Balkan Ülkeleri ve Türkiye’nin Makroekonomik Göstergeleri (2017)

\begin{tabular}{llllllllll}
\hline & & & & & & & & & \\
\hline
\end{tabular}

Kaynak: T.C. Ticaret Bakanlığı, IMF, Dünya Bankas1, https://tradingeconomics.com/turkey/rating

Balkan ülkeleri içerisinde 13 bin km2 ile en küçük yüz ölçüme sahip ülkelerinden biri olan Karadağ, 2006 yılında bağımsızlığını ilan etmiş ve Avrupa Birliğine katılma müzakerelerine 2012'de başlamıştır. 2017 verilerine göre, 5 milyar dolar GSYH ve 813 dolar KBGSYH ile bölgenin en fakir ülkesidir. 625 bin nüfusa sahip Karadağ'ın en büyük ekonomik sorunu yüksek orandaki işsizliktir (\%16). Bölge içerisinde en düşük diş ticaret hacmine (2.682 Milyar dolar) sahip olan Karadağ’ın çeşitli bölgeleri arasında, gelişmişlik ve ekonomik faaliyetler bakımından farklılıklar bulunmaktadır. IYK bakımından 51 ve KRE'de 71.sırada yer alan Karadağ, küçük ve nisbi olarak az sorunlu olma özelliği nedeniyle AB'ne üye olmaya en yakın ülke olduğu kabul edilmektedir (Güngör, 2016, s. 279-280).

Bölge ülkeleri içerisinde siyasi bağımsızlı̆̆ını en son kazanan Kosova yaklaşık 2 milyon nüfusu (1.831.000) ve $10.908 \mathrm{~km} 2$ yüzölçümüyle nispi olarak küçük bir ülkedir. Yüksek düzeyde kayıt dış1 ekonomiye sahip olan ülke, 2008 küresel krizinin ortaya çıkardığı ekonomik daralmadan sonra, özellikle de 2014 yllından itibaren istikrarlı bir büyüme göstermiştir. 2017 yllı itibariyle 7 milyar dolar GSYH ve \%5,9 büyümeyi başarmıştır. Bölgenin en düşük KBGSYH'na (3.893 dolar) sahip olan ülkede, diş ticaret bilançosu önemli bir sorun teşkil etmektedir. 2017 yllında 420 milyon dolar ihracat yapan ülke, aynı yıl 3.450 milyon dolarlık ithalat gerçekleştirmiştir. \%30.4 gibi yüksek işsizlik oranına sahip olan Kosova ekonomisi küçük, uluslararası tanınırlığ tartışmalı ve siyasi sorunları çözüme kavuşamamış bir ülkedir.

2016'da AB'ne aday statüsü kazanan Bosna-Hersek 51.197 km²'lik yüz ölçüme ve 3.507 .000 nüfusa sahip bir ülkedir. 1990'larda yaşanan savaş nedeniyle piyasa reformlarını gerçekleştiremeyen BosnaHersek'in gevşek federal yapısı ekonomi politikalarının koordinasyonunu ve reformları geciktirmektedir. $\mathrm{Bu}$ durum küresel krizle birlikte yabancı sermaye yatırımlarını da olumsuz yönde etkilemektedir (Güngör, 2016, s. 283-284). 2017 yılında IYK sıralamasında 81. sırada yer alan ülke yine aynı yıl 18 milyar dolar GSYH ve \%3 büyüme gerçekleştirmiştir. 2017 yllında KBGSYH's1 yaklaşık beş bin dolar olan BosnaHersek'te, gerek küresel krizin etkileri gerekse ülkedeki siyasi istikrarsızlık istihdamı olumsuz yönde etkilemiş, işsizlik oranı \%38,7 olarak gerçekleşmiştir. Aynı dönemde $(\% 1,1)$ gibi çok düşük enflasyonun yaşandığı ülkede, ihracat 6.366, ithalat 10.444 dolar düzeyinde gerçekleşmiştir.

1991 yılında bağımsızlı̆ııı kazanan ve 2009'da AB ile tam üyelik müzakerelerine başlanması yönünde tavsiye kararı alınan Makedonya, hala planlı ekonomiden piyasa ekonomisine geçiş aşamalarının uyum 
sürecini yaşamaktadır. 2017 yllında 11 milyar dolar GSYH'ye sahip olan Makedonya, Avrupa ile geliştirdiği güçlü bankacılık ilişkileri ve ekonomik ilişkiler sebebiyle Avrupa karşısında hassas bir ekonomiye sahiptir.

2008 Küresel krizinin olumsuz etkileri, yatırımlarda olduğu kadar kredi miktarının düşmesinde ve dış ticaret açı̆̆ının artmasında da görülmektedir. 2017 y1lı itibariyle 236 milyon dolar doğrudan yabancı sermaye girişi ile bölgede en alt sırada yer alan Makedonya'da, \%23 olan işsizlik oranı düşük enflasyonlu $(\% 1,3)$ ve makroekonomik istikrara sahip ülke ekonomisi için bir sorun teşkil etmektedir. Ancak GSYH'dan daha fazla dış ticaret hacmi (13 milyar dolar) Makedonya ekonomisini küresel krizlerden diğer Balkan ülkelerine oranla daha az etkilemektedir. Bunun nedeni, Makedonya ekonomisinin ve özellikle finans piyasasının küresel ekonomiye henüz uyum sağlayamamış olmasıdır. Diğer taraftan, 2017'de Bölge ülkeleri arasında en fazla brüt tasarruf/GSMH oranına sahip olan Makedonya, IYYK bakımından 50. sırada bulunmaktadir.

20 milyonluk nüfusu ve \%6,9 büyüme hızıyla bölgede Türkiye'den sonra ikinci sırada bulunan Romanya 2007 'de $A B^{\prime} y e$ tam üye olmuştur. Bölgede en düşük işsizliğe $(\% 4,2)$ sahip olan Romanya'nın yaşadığ en önemli problemlerin başında, ekonominin büyük oranda kayıt dışı olması ve vergi sistemine düşük oranda katk1 sağlayabilen kırsal nüfusun yüksek olmas1 gelmektedir(www.ticaret.gov.tr). Bölge içerisinde IYK açısında ilk sırada (36) yer almaktır. Türkiye'den sonra bölgede en fazla doğrudan yabancı sermaye yatırımlarına ve dış ticaret hacmine (150 Milyar Dolar) sahip olan ayrıca ihracatının \%70'den fazlasını AB'ye gerçekleştiren Romanya'da, Euro Bölgesi'nde yaşanmakta olan krizin makroekonomik değerler üzerindeki etkisi devam etmektedir.

Bulgaristan, serbest piyasa ekonomisi kurallarının geçerli olduğu ve özel sektörü orta düzeyde gelişmiş bir ülkedir. 2017 verilerine göre, 57 milyar dolar GSYH, \%6,2 işsizlik ve 8.312 dolar KBGSYH sahip olan Bulgaristan, incelediğimiz ülkeler arasında Makedonya'dan sonra en yüksek $(\% 26,9)$ brüt tasarruf/GSYH oranına sahip üst orta gelirli bir ekonomidir. Diğer taraftan, AB'ne 2007 yllında tam üye olan Bulgaristan, bu süreçte KBGSYH'nı AB ortalamasının \% 41'inden \% 47'sine yükselmiş, yoksulluk ve sosyal dışlanma tehlikesi altndaki nüfusun oran1 \% 60’tan \% 41,3’e düşürmüştür. Ancak, kaydedilen olumlu gelişmelere rağmen Bulgaristan, 8.312 dolar KBGSYH ile AB'nin en fakir ülkesi olmaya devam etmektedir (Sofya Ticaret Müşavirliği, 2018, s. 25).

2013 y1linda AB'ye tam üye olan Hirvatistan, 2017 yllinda 55 milyar dolar GSYH, 13.092 dolar KBGSYH ve oldukça düşük enflasyona (\%1) sahip bir ülkedir. Avrupa'da krizin neden olduğu durgunluk ihracatının \%60'ından fazlasını hâlihazırda $\mathrm{AB}$ ülkeleri ile yapmakta olan Hırvatistan ekonomisini olumsuz yönde etkilemektedir. 2017 verilerine göre \%11 gibi yüksek işsizlik oranı, büyüyen ticaret açığı, dengesiz kalkınma, yüksek dış borç ve turizm gelirlerine aşırı bağımlılığ ülke ekonomisinin hala devam etmekte olan sorunlaridir.

1991'de merkezi planlı ekonomi modelinden serbest piyasa ekonomisine geçen Arnavutluk'ta, fiyatların devlet kontrolünden çıkartılması, özelleştirme programlarının uygulanması ve dış ticaretin serbestleştirilmesi gibi birçok ekonomik reform uygulanmış olsa da, ülkede makroekonomik istikrarın sağlanması ve sürdürülebilir büyüme noktasında sorunlar devam etmektedir. 2017 yılı itibariyle yaklaşı 3 milyon nüfus ve 13 milyar dolar GSYH sahip olan ülke, Kosova'dan sonra bölgenin en düşük KBGSYH (4.537 bin dolar) sahip ülkesidir. Aynı dönemde \%1,9 oranında düşük enflasyonun yaşandığı ülkede en önemli sorunların başında $\% 13,8$ oranına ulaşan işsizlik ve diğer bölge ülkelerinde olduğu gibi dış ticaret açığ1 gelmektedir. Nitekim 2017 yılında ihracat 2,261, ithalat 5,717 dolar düzeyinde gerçekleşmiştir. IYYK endeksinde 58. sırada yer alan Arnavutluk, artan dış ekonomik ve ticari ilişkileri ve yabancı yatırımların etkisiyle ekonomik alanda bir dönüşüm süreci yaşanmaktadır. Ancak ülkede mali konsolidasyonun sürdürülmesi, kayıt dışı ekonominin ortadan kaldırlması, üretimin ve istihdamın arttırılmasına yönelik çabalar yeterince sonuç vermemektedir (T.C. Dış İşleri Bakanlı̆̆1, 2018).

Türkiye 2017 yllı itibariyle 80 milyon nüfusu ve 851 milyar dolarlık GSYH'si ile bölgenin en büyük ekonomisine sahip olan ülkesidir. Türkiye'yi 212 milyar dolar ile Romanya, 200 milyar dolar ile Yunanistan, 57 milyar USD ile Bulgaristan izlemektedir.

2007-2017 döneminde Türkiye ekonomisi yaklaşık olarak \%30 oranında büyüme ile bölge içerisinde en hızlı gelişmeyi gösterirken, Yunanistan ekonomisi yaklaşık olarak \%50 oranında daralmışıı. Bölge ülkeleri içerisinde ekonomisinde değişim görülmeyen ülke ise Karadağ’dır. Hırvatistan ve Yunanistan Dünya Bankası ülke sınıflandırmasına göre yüksek gelir grubunda yer alırken, Bulgaristan, Bosna-Hersek, Arnavutluk, Makedonya Kosova Romanya Sırbistan üst orta gelir grubunda bulunmaktadır. Diğer taraftan 
Balkan ülkeleri içerisinde 2017 yllı itibariyle Yunanistan 23.027 dolar KBGSYH ile ilk sırada yer alırken Türkiye 14.933 dolar ile ikinci ve 13.092 dolar ile de Hirvatistan üçüncü sırada takip etmektedir.

2017 y1lı itibariyle bölge ülkeleri içerisinde en yüksek işsizlik oranı \%38,7 ile Bosna-Hersek'e aittir. Bosna Hersek'in ardından en yüksek işsizlik oranına sahip ülkeler olarak \%23,7 ile Makedonya ve \%21,4 ile Yunanistan gelmektedir. En düşük işsizlik oranına sahip ülkeler ise \% 4,2 ile Romanya, \%6,2 ile Bulgaristan ve \%11 ile Hırvatistan'dır. 2017 yılında bölge ülkeleri içerisinde enflasyon oranı en yüksek olan ülke \%11,9 ile Türkiye'dir. Türkiye'yi \%3,1 ile Sırbistan ve \%2,4 ile Karadağ takip etmektedir. Ayn1 yıl Yunanistan, Hırvatistan ve Bosna-Hersek \%1,1 oranı ile en düşük enflasyona sahip ülkelerdir.

Bölge içerisinde 2017 yll itibariyle en yüksek doğrudan yabancı sermaye girişinin gerçekleştiği ve Brüt yatıım/GSYH oranına sahip olan Türkiye, aynı yıl yaklaşık 400 milyar dolar dış ticaret hacmi ile ilk sırada yer alırken, Türkiye"yi 70 milyar dolarlık ihracat değeri ile Romanya, 32 milyar dolar ihracatı ile Yunanistan takip etmektedir. En düşük ihracat ise 420 ve 428 milyon dolar ile Karadağ ve Kosova tarafından gerçekleştirilmiştir. Aynı dönemde en yüksek ithalat 233 milyar dolar ile Türkiye ilk sırada yer alırken Türkiye'yi 85 milyar dolar ile Romanya, 56 milyar dolar ile Yunanistan izlemektedir. Bölge ülkeleri çerisinde en düşük ithalat ise 2,6 milyar dolarla ile Karadağ, 3,4 milyar dolar ile Kosova ve 5,2 milyar dolar ile Arnavutluk tarafindan gerçekleştirilmiştir.

\section{Balkan Ülkeleri ve Türkiye'de Kırılganlık Göstergeleri}

Çalışmanın bu bölümünde Balkan ülkeleri ve Türkiye'yi makroekonomik kırılganlık yönünden karşılaştırmak adına literatürde de kullanılan göstergelerden yararlanarak 2007-2017 dönemi için bütçe dengesi/GSYH, kamu borcu/GSYH, cari denge/GSYH, döviz rezervi/GSYH, ylllk kredi büyümesi ve kredi/mevduat göstergeleri seçilerek ülkelerin makroekonomik performansları karşılaştırmalı olarak analiz edilmiştir.

\section{Mali Kırılganlık Göstergeleri}

Ülkelerin kamu maliyesinin performansı hakkında bilgi veren iki önemli mali kırılganlık göstergelerinden biri bütçe dengesi/GSYH, diğeri de kamu borcu/GSYH’ye oranıdır. Aşağıda Balkan ülkeleri ve Türkiye'nin mali kırrlganlık göstergeleri incelenmiştir.

\section{Bütçe Dengesi}

Ülkelerin ekonomik performansını, kamu maliyesinin sağlamlığ1 dolayısıyla kırılganlığ1 yansıtan en önemli göstergelerden biri kamunun gelir ve giderlerinin farkı olan bütçe dengesi veya dengesizliğidir. Kamudaki bütçe açığı para arzının artması, yeni vergilerin konması veya borçlanma gibi makroekonomik dengeler üzerinde olumsuz sonuçlara yol açmaktadır (Eleren ve Karagül, 2008, s. 4).

Bu nedenle bütçe dengesinin GSYH'ye oranı bir ülkenin ne derece sağlam bir kamu maliyesine sahip olduğunu görmek açısından önemlidir. Çünkü açığın büyümesi ülkenin borçlanma gereğini arttırarak borçların sürdürülebilirliğini zorlaştırdığı gibi sermaye girişlerinde daralmaya ve makroekonomik dengelerin bozulmasına yol açmaktadır.

Aşağıda Tablo 2'de 2007- 2017 döneminde Türkiye ve Balkan ülkelerinde bütçe dengesi/GSYH göstergesine yer verilmiştir. 2017 yllında bölge ülkelerinde en yüksek bütçe dengesi/GSYH oranına sahip ülke - $\% 6,95$ ile Karadağ'dır. Bu ülkeyi - \%2,82 ile Romanya ve - $\%$ 2,72 ile Makedonya takip etmektedir. Bölge ülkeleri arasında en düşük bütçe dengesi/GSYH oranına sahip ülke ise \% 2.05 ile Bosna Hersek'tir.

2007- 2017 dönemindeki ortalamaya göre en riskli ülke konumunda olan Yunanistan -\% 6,7’lik oran ile ilk sırada yer alırken, Yunanistan'1 - $\%$ 4,5 ile Hirvatistan, - \% 3,8 ile Karadağ ve Arnavutluk takip etmektedir. 


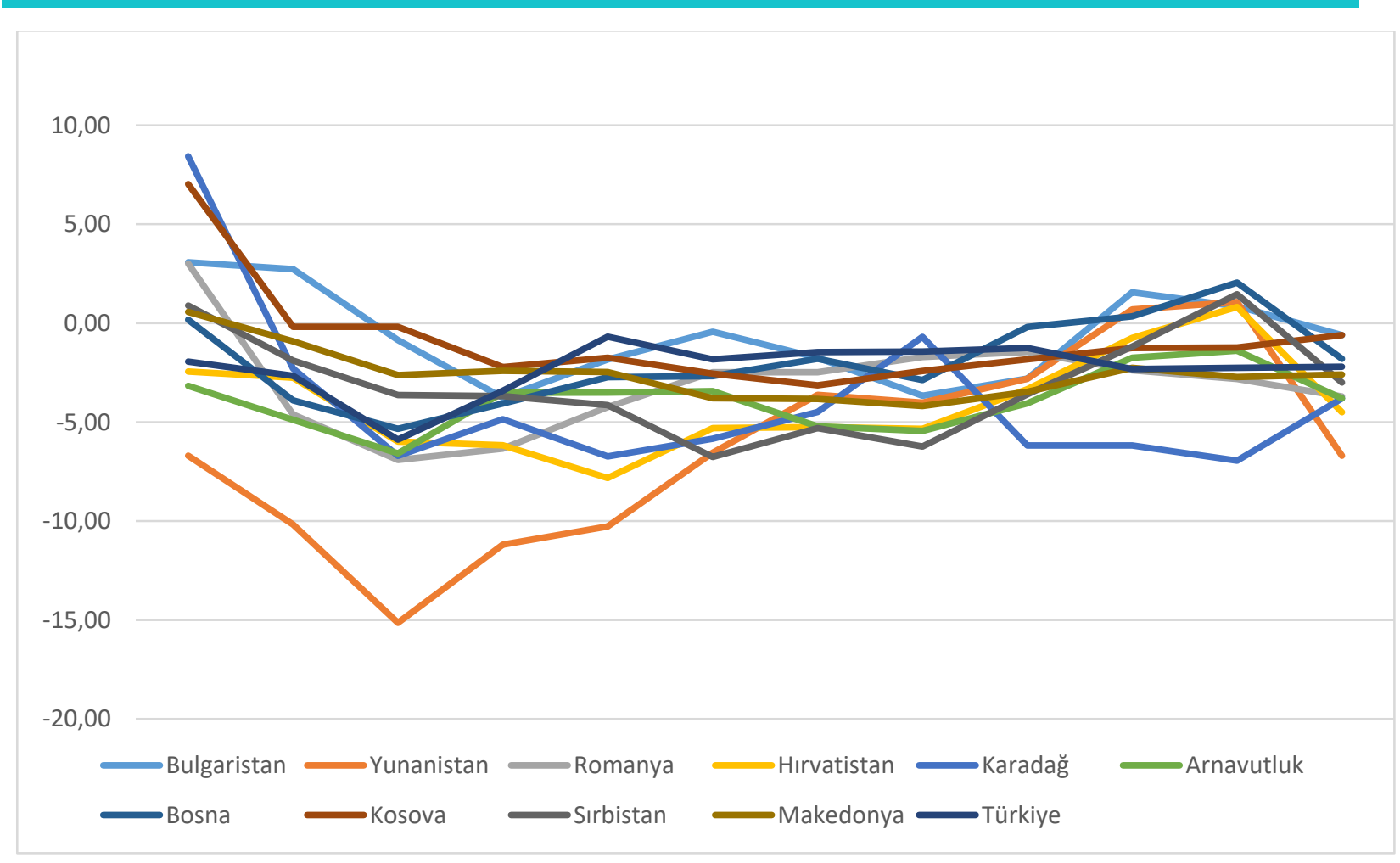

Şekil 1. Bütçe Dengesi / GSYH Oranlar (\%)

Tablo 2. Bütçe Dengesi /GSYH Oranları (\%)

\begin{tabular}{lllllllllllll}
\hline Ülke/Y11 & $\mathbf{2 0 0 7}$ & $\mathbf{2 0 0 8}$ & $\mathbf{2 0 0 9}$ & $\mathbf{2 0 1 0}$ & $\mathbf{2 0 1 1}$ & $\mathbf{2 0 1 2}$ & $\mathbf{2 0 1 3}$ & $\mathbf{2 0 1 4}$ & $\mathbf{2 0 1 5}$ & $\mathbf{2 0 1 6}$ & $\mathbf{2 0 1 7}$ & Ort \\
\hline Bulgaristan & 3.08 & 2.73 & -0.85 & -3.77 & -1.84 & -0.43 & -1.75 & -3.67 & -2.80 & 1.56 & 0.85 & -0.6 \\
\hline Yunanistan & -6.70 & -10.17 & -15.14 & -11.19 & -10.27 & -6.55 & -3.62 & -4.02 & -2.81 & 0.69 & 1.07 & -6.7 \\
\hline Romanya & 3.02 & -4.62 & -6.91 & -6.34 & -4.24 & -2.48 & -2.48 & -1.71 & -1.45 & -2.38 & -2.82 & -3.7 \\
\hline Hirvatistan & -2.44 & -2.76 & -5.98 & -6.17 & -7.82 & -5.30 & -5.25 & -5.34 & -3.34 & -0.75 & 0.82 & -4.5 \\
\hline Karadağ & 8.43 & -2.29 & -6.71 & -4.86 & -6.73 & -5.84 & -4.49 & -0.69 & -6.18 & -6.18 & -6.95 & -3.8 \\
\hline Arnavutluk & -3.17 & -4.88 & -6.58 & -3.52 & -3.51 & -3.44 & -5.21 & -5.45 & -4.05 & -1.75 & -1.39 & -3.8 \\
\hline Bosna & 0.17 & -3.90 & -5.34 & -4.06 & -2.73 & -2.68 & -1.80 & -2.87 & -0.19 & 0.34 & 2.05 & -1.8 \\
\hline Kosova & 7.03 & -0.18 & -0.63 & -2.22 & -1.75 & -2.55 & -3.14 & -2.42 & -1.83 & -1.26 & -1.23 & -0.6 \\
\hline Surbistan & 0.89 & -1.89 & -3.63 & -3.69 & -4.14 & -6.76 & -5.30 & -6.23 & -3.60 & -1.18 & 1.46 & -3.0 \\
\hline Makedonya & 0.57 & -0.92 & -2.62 & -2.41 & -2.47 & -3.79 & -3.83 & -4.19 & -3.47 & -2.26 & -2.72 & -2.6 \\
\hline Türkiye & -1.94 & -2.66 & -5.88 & -3.42 & -0.68 & -1.83 & -1.46 & -1.43 & -1.26 & -2.32 & -2.26 & -2.2 \\
\hline Kaynak: & & & & & & & & & & & &
\end{tabular}

Kaynak: IMF, Dünya Bankası, https://unctadstat.unctad.org

Balkan ülkelerinden Yunanistan ve Hirvatistan'da bütçe açı̆̆ı tehlikeli düzeylerde iken, Türkiye'nin bu ülkelere göre daha düşük oranlı bütçe açığına sahip olması risk algısının azaldığını ve sıkı maliye politikasının başarısını göstermektedir. Bütçe açığı konusunda önemli bir sorun yaşamayan Türkiye'de, bütçe açı̆̆ incelenen dönem içinde daha çok -\% 1-2,5 dolaylarında iken, 2008 finansal kriziyle 2009'da -\% 5,8’e yükselmiş, 2011'de azalarak -\% 0,68'e gerilemiştir.

\section{Kamu Borcu}

Ülkelerin makroekonomik kırlganlık ekonomik kırllganlık düzeyi belirlenirken, değerlendirilmesi gereken en önemli göstergelerden biri de Kamu Borcu/GSYH oranıdır.

$\mathrm{Bu}$ kriter ekonomik büyümeyi sürdürmek ve küresel likidite sıkışıllığ1 durumunda bankaları desteklemek için ihtiyaç duyulan ek finansman gibi durumlarda artan borç yükünün sürdürülebilirliğini değerlendirir (Moody's, 2014, s. 6).

Kamu Borcu/GSYH oranının yüksek olduğu ekonomilerde borcun geri ödenme durumu riskli olduğu gibi, özel sektöre ayrılan kredi payı da düşük düzeylerde gerçekleşecek ve ekonominin kırrlganlığ1 artıracaktır (Bayraktar ve Elüstü, 2016, s. 18). 


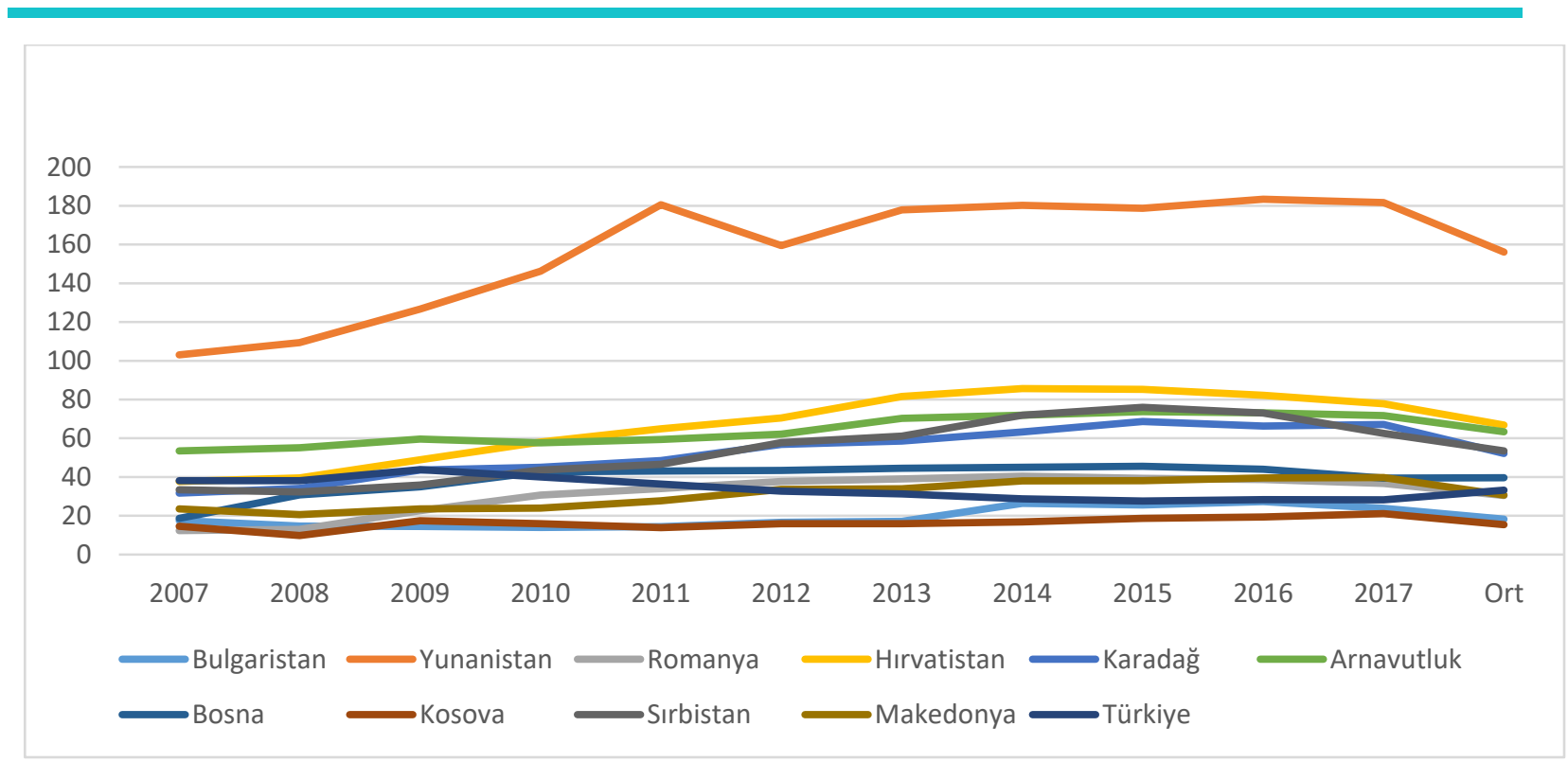

Şekil 2. Kamu Borcu/GSYH Oranlarn (\%)

Tablo 3. Кати Borcu/GSYH Oranları (\%)

\begin{tabular}{|c|c|c|c|c|c|c|c|c|c|c|c|c|}
\hline Ülke/Y1l & 2007 & 2008 & 2009 & 2010 & 2011 & 2012 & 2013 & 2014 & 2015 & 2016 & 2017 & Ort \\
\hline Bulgaristan & 17.5 & 14.7 & 14.5 & 14.0 & 14.4 & 16.6 & 17.1 & 26.4 & 25.6 & 27.3 & 23.9 & 18.3 \\
\hline Yunanistan & 103.1 & 109.4 & 126.7 & 146.2 & 180.5 & 159.5 & 177.9 & 180.2 & 178.7 & 183.4 & 181.7 & 156.1 \\
\hline Romanya & 12.3 & 13.0 & 22.6 & 30.7 & 34.0 & 37.7 & 39.0 & 40.4 & 39.3 & 38.7 & 36.7 & 30.5 \\
\hline Hirvatistan & 37.7 & 39.5 & 48.9 & 58.1 & 64.9 & 70.5 & 81.6 & 85.7 & 85.2 & 82.2 & 77.8 & 66.8 \\
\hline Karadağ & 31.7 & 34.1 & 43.6 & 45.0 & 48.5 & 56.8 & 58.6 & 63.3 & 68.7 & 66.3 & 67.1 & 52.2 \\
\hline Arnavutluk & 53.5 & 55.1 & 59.6 & 57.7 & 59.4 & 62.1 & 70.3 & 71.9 & 73.7 & 73.1 & 71.7 & 63.4 \\
\hline Bosna & 18.7 & 30.8 & 35.0 & 42.7 & 43.1 & 43.4 & 44.5 & 45.0 & 45.5 & 44.0 & 39.4 & 39.6 \\
\hline Kosova & 14.6 & 9.8 & 17.4 & 15.9 & 13.9 & 15.9 & 15.9 & 16.8 & 18.7 & 19.4 & 21.1 & 15.4 \\
\hline S1rbistan & 33.4 & 32.3 & 35.9 & 43.6 & 46.6 & 57.8 & 61.1 & 71.9 & 76.0 & 73.0 & 62.5 & 53.5 \\
\hline Makedonya & 23.5 & 20.6 & 23.5 & 24.0 & 27.7 & 33.6 & 33.9 & 38.0 & 38.1 & 39.5 & 39.7 & 30.7 \\
\hline Türkiye & 38.1 & 38.1 & 43.8 & 40.0 & 36.4 & 32.7 & 31.3 & 28.7 & 27.6 & 28.3 & 28.2 & 33.2 \\
\hline
\end{tabular}

Kaynak: IMF, Dünya Bankas1, https://unctadstat.unctad.org

Moody's'e göre, Kamu Borcu/GSYH oranının \%40'ın altında olması kırılganlığın az olduğunu, \%40 ve $\% 60$ arasında olması kırılganlığın orta derecede, $\% 60$ ve üzeri olması da kırılganlığın yüksek düzeyde olduğunu ifade etmektedir.

Tablo 3'de Türkiye ve Balkan ülkelerindeki kamu borcunun GSYH içindeki payları verilmiştir. 2017 yilında kamu borcu/ GSYH oranı en düşük ülkeler sırasıyla \%21 oranılla Kosova, \%23 oranıyla Bulgaristan, \%28 oranıyla Türkiye ve \%36 oranıla Romanya olurken; bu oranın en yüksek olduğu ve bu nedenle kırılganlığa yol açtı̆̆ ülkeler ise öncelikle \%181 ile Yunanistan, ardından da \%77 ile Hırvatistan ve $\% 71$ ile Arnavutluk'tur.

Tablo 3'e göre, 2007-2017 döneminde ortalama kamu borcunun GSYH içindeki payı \%40'n altında olan dolayısıyla kırllganlığı az olan ülkeler Bulgaristan, Romanya, Bosna-Hersek, Kosova, Türkiye ve Makedonya'dır. Kırlganlığı en yüksek olan ülke \% 156 ile Yunanistan'dır bu ülkeyi \% 66 ile Hırvatistan, \%63 ile Arnavutluk takip etmektedir. Kamu borcunun GSYH içindeki payı 2007-2017 döneminde sürekli artan ülke Makedonya'dır.

Son olarak kamu borcu/GSYH oranı Türkiye açısından incelendiğinde, oran incelenen dönem içinde azalma eğilimi göstermiştir. Fakat küresel kriz nedeniyle 2009 yllında artmıştır. 2009 yllında $\% 43,5$ olan oran ilerleyen y1llarda sürekli azalarak 2017 yllinda \%28,2 düzeyinde gerçekleşmiştir. Bölge ülkeleri içerisinde 2017 ylı kamu borcu/GSYH oranı göz önüne alındığında Türkiye en iyi üçüncü ülke konumundadir.

Türkiye açısından kamu borcu/GSYH oranı incelendiğinde, dönem başından itibaren azalma eğiliminde olan oran küresel krizin etkisiyle 2009 yllında \%43,5 olarak gerçekleşmiştir. 2010'dan itibaren tekrar azalma eğilimine giren kamu borcu/GSYH oran1 2017 yll itibariyle \%28,2 düzeyinde gerçekleşmiştir. Bölge ülkeleri içerisinde 2017 ylı kamu borcu/GSYH oranı göz önüne alındığında, Türkiye en iyi üçüncü ülke konumundadır. 


\section{Cari Denge}

Cari denge, bir ülkenin diş dünya ile yaptığı borçlu veya alacaklı işlemler içerisinde diş ticaret, hizmetler, net yatırım gelirleri ve net karşılıksız transfer dengelerinin toplamından elde edilen değerdir (Bayrak ve Esen, 2012, s. 27-28). Cari dengenin toplamının negatif olması veya diğer bir ifadeyle ülkenin cari işlemlerden elde ettiği döviz gelirlerinin cari işlemlere yapılan döviz giderlerinden daha az olması durumu, cari açık ya da cari işlemler açı̆̆1 (tersi durumda ise cari fazla ya da cari işlemler fazlası) olarak nitelendirilir.

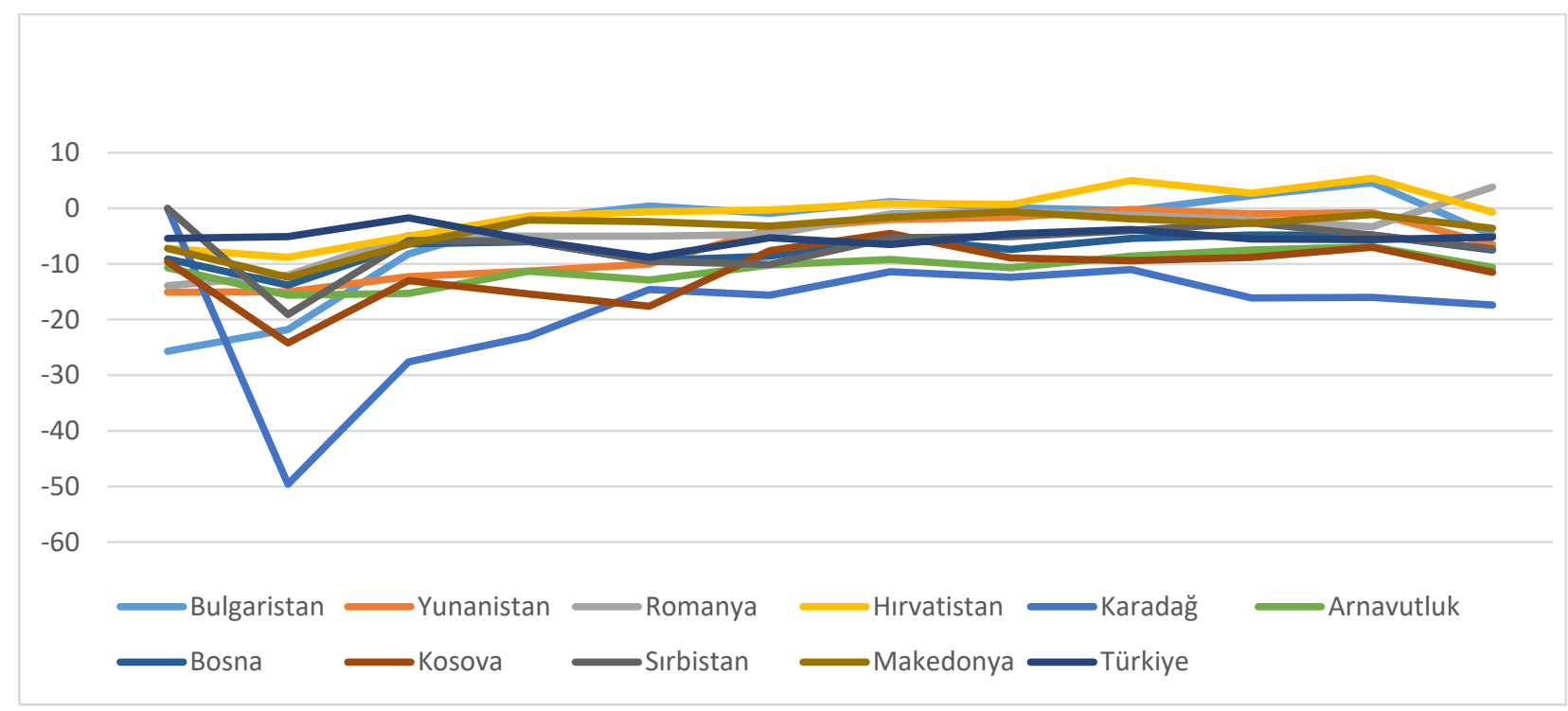

Şekil 3. Cari Denge/GSYH Oranlarn (\%)

Tablo 4. Cari Denge/GSYH Oranlarn (\%)

\begin{tabular}{lllllllllllll}
\hline Ülke/Y1l & 2007 & 2008 & 2009 & 2010 & 2011 & 2012 & 2013 & 2014 & 2015 & 2016 & 2017 & Ort \\
\hline Bulgaristan & -25.7 & -21.8 & -8.2 & -1.9 & 0.4 & -0.9 & 1.2 & 0.1 & -0.4 & 2.3 & 4.6 \\
Yunanistan & -15.1 & -15.0 & -12.3 & -11.3 & -10.0 & -3.8 & -2.0 & -1.6 & -0.2 & -1.0 & -0.8 & -6.8 \\
Romanya & -13.9 & -12.0 & -4.9 & -5.0 & -5.0 & -4.7 & -1.0 & -0.6 & -1.2 & -2.1 & -3.3 & 3.8 \\
Hirvatistan & -7.2 & -8.8 & -5.0 & -1.4 & -0.6 & -0.3 & 0.9 & 0.7 & 5.0 & 2.7 & 5.4 & -0.7 \\
Karadağ & - & -49.6 & -27.6 & -23.0 & -14.6 & -15.6 & -11.4 & -12.4 & -11.0 & -16.1 & -16.0 & -17.4 \\
Arnavutluk & -10.7 & -15.6 & -15.3 & -11.3 & -12.9 & -10.2 & -9.2 & -10.7 & -8.6 & -7.5 & -6.9 & -10.6 \\
Bosna & -9.1 & -13.8 & -6.4 & -6.0 & -9.4 & -8.6 & -5.3 & -7.4 & -5.4 & -4.8 & -4.8 & -7.5 \\
Kosova & -9.6 & -24.2 & -13.0 & -15.4 & -17.6 & -7.6 & -4.5 & -8.9 & -9.4 & -8.8 & -7.0 & -11.5 \\
Sirbistan & - & -19.1 & -5.8 & -5.9 & -9.5 & -10.1 & -5.3 & -5.1 & -4.0 & -2.6 & -4.8 & -7.3 \\
Makedonya & -7.2 & -12.4 & -6.4 & -2.1 & -2.4 & -3.2 & -1.6 & -0.6 & -1.9 & -2.7 & -1.1 & -3.6 \\
Türkiye & -5.4 & -5.1 & -1.7 & -5.7 & -8.8 & -5.3 & -6.5 & -4.6 & -3.8 & -5.5 & -5.6 & -5.2 \\
\hline
\end{tabular}

Kaynak: IMF, Dünya Bankası, https://unctadstat.unctad.org

Cari işlemler açığında meydana gelen artış, yatırımcıların davranışlarında değişikliklere neden olmakta ve bunun sonucunda yatırımciların yerli para cinsinden varlıklara ilgisinin azalmasına ve döviz kuru ile varlık fiyatlarının değer kaybetmesine yol açabilmektedir (Moody's, 2014, s. 3). Bu durum ise ülkeyi ekonomik krizlere ve dışşoklara karşı çok daha kırılgan hale getirebilmektedir.

Cari işlemler açı̆̆ı; yabancı sermaye akımı (doğrudan veya portföy yatırımları) veya yurtiçi varlıkların satılması ile finanse edilmektedir. Cari işlemler açı̆̆ını kapatmak için dış finansmana bağlılık ise, ülkeleri yatırımcıların risk algısındaki değişmelere karşı daha kırılgan hale getirebilmektedir (Karakurt vd., 2015, s. 297).

Cari açığın ne kadar olması gerekliliğinden çok, sürdürülebilir olması çok daha önemlidir. Cari açık/GSYH oranının \%4-5'lik eşik değerin üzerine çıkması ekonomi için olası bir krizin göstergesi olarak algılanmaktadır. Cari açık/GSYH oranı artıkça yabancı sermayeye olan ihtiyacın şiddeti artacağından dolayı döviz kurları üzerinde bask1 meydana getirmektedir.

Yukarıda Tablo 4'de 2007-2017 döneminde Balkan ülkeleri ve Türkiye'de cari denge/GSYH göstergesine yer verilmiştir. 
2017 'de en yüksek cari açığa sahip olan ülke -\%16 ile Karadağ'dır. Karadağ’’ - \% 7,0 ile Kosova -\%6,9 ile Arnavutluk, takip etmektedir. Cari açıkta kendilerine pozitif bir ivme çizen Hırvatistan \% \%5,4 ile ve Bulgaristan, \%4,6 ile kendilerini gruplandırmanın biraz daha dışında bırakıyor gibi görünmektedirler

2007-2017 dönemine ilişkin 11 yıllık ortalamalara göre en yüksek cari açık/GSYH oranına sahip ülkenin -\%17,4 ile Karadağ olduğu dolayısıyla da kırılganlığın en yüksek olduğu ülke konumundadır. Karadağ’1 - \% 11,5 ile Kosova, - \% 10,6 ile Arnavutluk takip etmektedir. Bu oranlar \%5’in üzerinde olduğu için yüksek oranda risk oluşturmaktadırlar.

Bölge ülkeleri genellikle cari açık vermektedirler. Tablo 4'e göre 2007-2017 döneminde 2008 yılı cari açıkta artışların, 2013 yılı ise cari açıklarda düşüşlerin en çok olduğu dönem olarak görülmektedir.

\section{Döviz Rezervi}

Ekonomik ve finansal şoklara karşı ülkelerin kırılganlığını azaltan önemli bir gösterge de döviz rezervleridir. Ülkelerin içinde bulundukları ekonomik şartların farklı olmasından dolayı optimal döviz rezervini belirlemek zor olmasına rağmen optimal rezerv düzeyini tespit etmek için geliştirilen çeşitli ölçütler bulunmaktadır. Bunlar rezervlerin ithal edilen mal ve hizmetlere oranı ve rezervlerin kısa vadeli borçlara oranıdır. Yüksek rezerv risk primini, dolayısıyla borçlanma maliyetini düşürürken; düşük olması yerli ve yabancı yatırımların azalmasına veya yatırım için yüksek risk primi talebine neden olmaktadır (TCMB, 2005, s. 4-6). Bu nedenle uluslararası döviz rezervleri/GSYH oranının yüksek olması gerekmektedir.

Aşağıda Tablo 5'de Türkiye ve Balkan ülkelerinin döviz rezervlerinin GSYH'ye oranları verilmiştir. 2017 yıllında Türkiye ve Balkan ülkelerinde döviz rezervi/GSYM oranı en yüksek olan ülke \%45 ile Bulgaristan olurken, bu ülkeyi \%35 ile Bosna, \%27 ile Arnavutluk takip etmektedir.

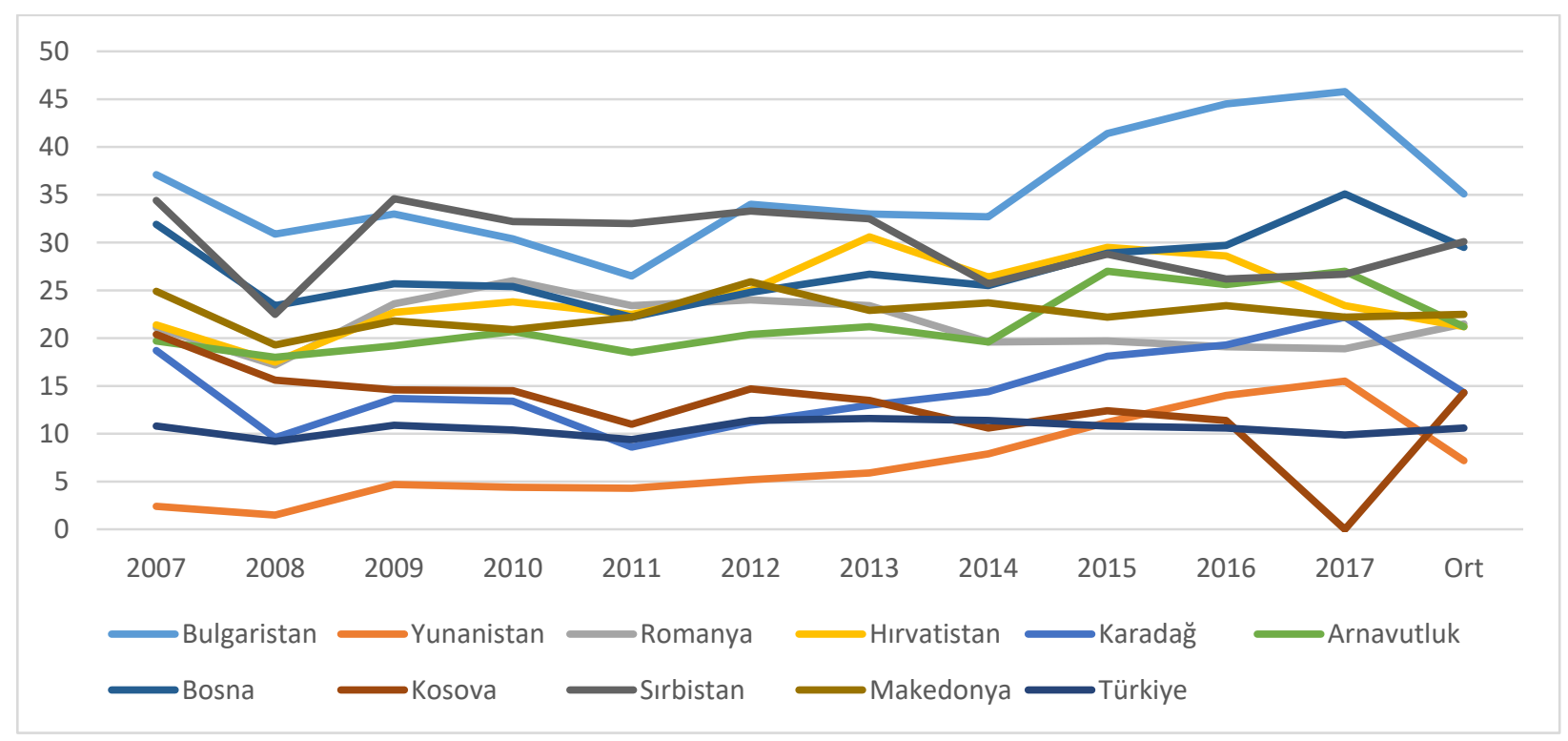

Şekil 4. Döviz Rezervi / GSYH Oranlarn (\%)

Tablo 5. Döviz Rezervi / GSYH Oranlar (\%)

\begin{tabular}{|c|c|c|c|c|c|c|c|c|c|c|c|c|}
\hline Ülke/Y1l & 2007 & 2008 & 2009 & 2010 & 2011 & 2012 & 2013 & 2014 & 2015 & 2016 & 2017 & Ort \\
\hline Bulgaristan & 37,1 & 30,9 & 33,0 & 30,4 & 26,5 & 34,0 & 33,0 & 32,7 & 41,4 & 44,5 & 45,8 & 35.1 \\
\hline Yunanistan & 2.4 & 1.5 & 4.7 & 4.4 & 4.3 & 5.2 & 5.9 & 7.9 & 11.2 & 14.0 & 15.5 & 7.2 \\
\hline Romanya & 21,1 & 17,2 & 23,6 & 26,0 & 23,4 & 24,0 & 23,4 & 19,6 & 19,7 & 19,1 & 18,9 & 21,5 \\
\hline Hirvatistan & 21,4 & 17,5 & 22,7 & 23.8 & 22.5 & 25.0 & 30.6 & 26.4 & 29.5 & 28.6 & 23.4 & 21,2 \\
\hline Karadağ & 18,7 & 9,58 & 13,7 & 13,4 & 8,6 & 11,2 & 13,0 & 14,4 & 18,1 & 19,3 & 22,2 & 14,3 \\
\hline Arnavutluk & 19,7 & 18,0 & 19,2 & 20,7 & 18,5 & 20,4 & 21,2 & 19,6 & 27,0 & 25,6 & 27,0 & 21,2 \\
\hline Bosna & 31,9 & 23,4 & 25,7 & 25,4 & 22,2 & 24,8 & 26,7 & 25,5 & 28,9 & 29,7 & 35,1 & 29,5 \\
\hline Kosova & 20,4 & 15,6 & 14,6 & 14,5 & 11,0 & 14,7 & 13,5 & 10,6 & 12,4 & 11,4 & - & 14,3 \\
\hline Sirbistan & 34,4 & 22,5 & 34,6 & 32,2 & 32,0 & 33,3 & 32,5 & 25,7 & 28,8 & 26,2 & 26,7 & 30,1 \\
\hline Makedonya & 24,9 & 19,3 & 21,8 & 20,9 & 22,2 & 25,9 & 22,9 & 23,7 & 22,2 & 23,4 & 22,2 & 22,5 \\
\hline Türkiye & 10,8 & 9,2 & 10,9 & 10,4 & 9,4 & 11,4 & 11,6 & 11,4 & 10,8 & 10,6 & 9,88 & 10,6 \\
\hline
\end{tabular}

Kaynak: IMF, Dünya Bankas1, https://unctadstat.unctad.org 
2007-2017 döneminde ortalama döviz rezervlerinin GSYH'ye oranı en yüksek olan ülkeler sıralamasında \%35 ile Bulgaristan ilk sırada yer alırken bu ülkeyi \% 30 ile Sirbistan ve \%29 ile Bosna izlemektedir. Oranın en düşük olduğu ülkeler sıralamasında ise \%7ile Yunanistan ve \%10 Türkiye yer almaktadır. Ortalama ve birbirine yakın değerlere sahip olan Romanya, Hirvatistan, Kosova, Karadă̆, Arnavutluk ve Makedonya'da bu oran \%10-20 arasındadır. Ancak daha önce saydığımız ülkeler kadar düşük değerlere sahip olmamaları, bu göstergenin söz konusu ülkeler için kırılganlık oluşturmayacağ1 anlamına gelmez. Çünkü ülkelerin cari dengelerinde ortaya çıkan açık durumunda öncelikle rezervlere başvurulacağı için, cari açı̆̆ın yüksek olması rezerv miktarını yetersiz hale getirebilir. Yüksek cari açı̆̆a sahip ülkeler olarak Karadă̆, Kosova ve Arnavutluk, bu açığı finanse edebilecek yeterlilikte döviz rezervine sahip olmamaları durumunda, borçlanmaya başvurarak kırılganlıkları artacak konumundadır.

\section{Finansal Kırılganlık Göstergeleri}

Ülke ekonomilerinin durumu finansal sistemde bankacılık sektöründeki gelişmelerden de anlaşılabilmektedir. Çünkü etkin ve verimli çalışmayan bir bankacılık sektörü kırılganlıkların arttığının önemli bir göstergesidir. Finansal kırılganlık göstergesi olarak yıllık kredi büyüme oranlarını ve özel sektöre verilen yurtiçi kredilerin GSYH oranındaki değişmeleri incelemek ülkenin finans sistemi ve bankacilık sektörü hakkında gerekli bilgiyi vermektedir (Çan ve Dinçsoy 2016, s. 209). Aşağıda Balkan ülkeleri ve Türkiye'nin finansal kırılganlık göstergeleri incelenmektedir.

\section{Y1lık Kredi Büyüme Oranları}

Finansal sistemde risk oluşturan önemli finansal kır1lganlık göstergelerinden biri yıllık kredi büyüme oranlarıdır.

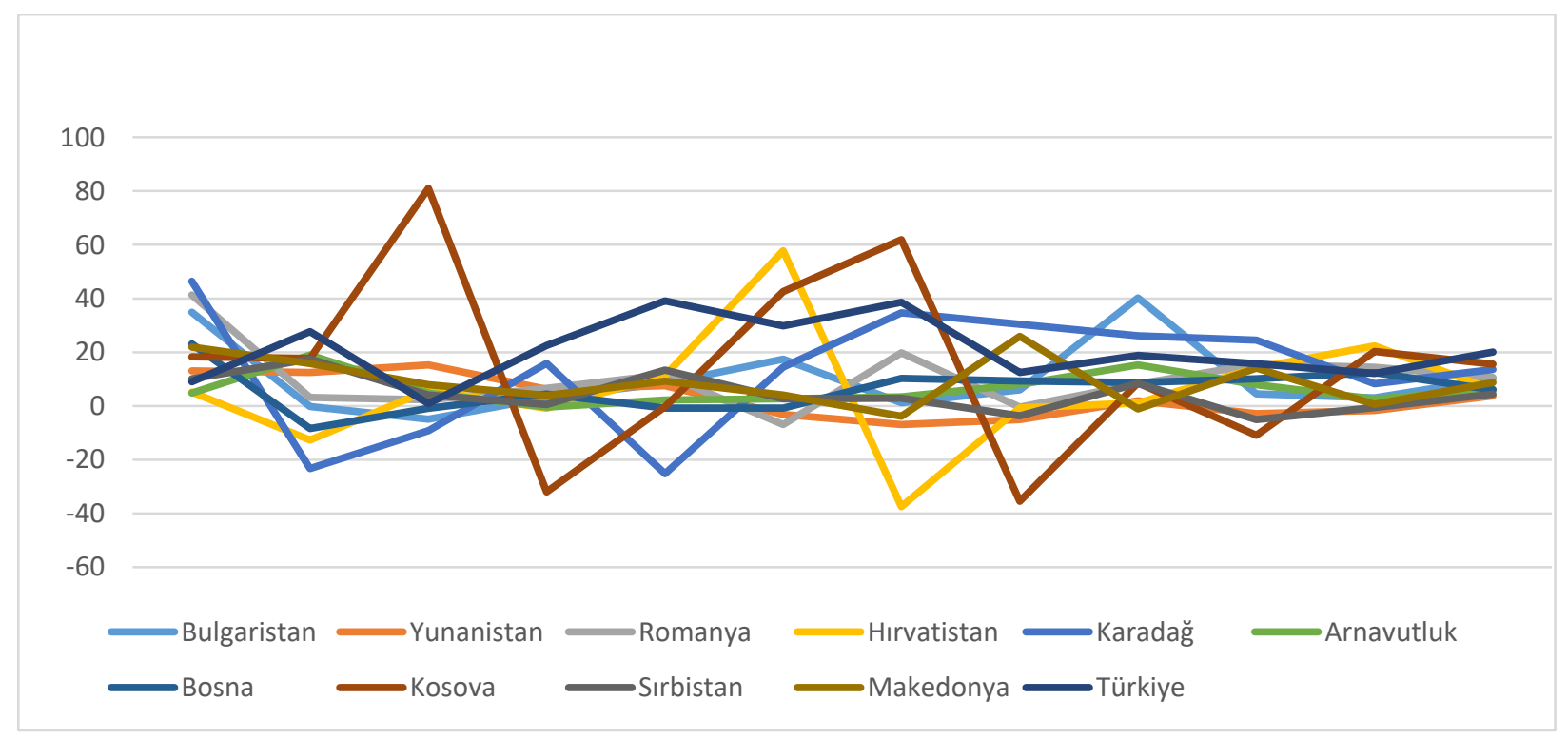

Şekil 5. Yullık Kredi Büyüme Oranlar (\%)

Tablo 6. Yillık Kredi Büyüme Oranları (\%)

\begin{tabular}{lllllllllllll}
\hline Ülke/Y1l & $\mathbf{2 0 0 7}$ & $\mathbf{2 0 0 8}$ & $\mathbf{2 0 0 9}$ & $\mathbf{2 0 1 0}$ & $\mathbf{2 0 1 1}$ & $\mathbf{2 0 1 2}$ & $\mathbf{2 0 1 3}$ & $\mathbf{2 0 1 4}$ & $\mathbf{2 0 1 5}$ & $\mathbf{2 0 1 6}$ & $\mathbf{2 0 1 7}$ & Ort \\
\hline Bulgaristan & 34.9 & -0.2 & -4.9 & 3.1 & 8.4 & 17.4 & 1.2 & 6.0 & 40.2 & 4.5 & 3.0 & 10.1 \\
Yunanistan & 13.1 & 12.5 & 15.3 & 6.2 & 7.5 & -3.2 & -6.9 & -5.1 & 1.9 & -2.9 & -1.7 & 3.8 \\
Romanya & 41.3 & 3.2 & 2.3 & 6.6 & 11.7 & -6.9 & 19.8 & -0.4 & 8.2 & 15.5 & 14.4 & 10.6 \\
Hirvatistan & 5.2 & -12.7 & 5.9 & -0.9 & 11.3 & 57.8 & -37.5 & -0.7 & 1.1 & 14.2 & 22.4 & 6.1 \\
Karadağ & 46.4 & -23.3 & -9.2 & 15.9 & -25.2 & 14.5 & 34.7 & 30.4 & 26.1 & 24.5 & 8.3 & 13.6 \\
Arnavutluk & 4.8 & 19.0 & 4.8 & -0.4 & 2.2 & 2.7 & 3.4 & 8.0 & 15.3 & 7.9 & 2.6 & 6.2 \\
Bosna & 23.1 & -8.4 & -0.9 & 4.4 & -0.8 & -0.8 & 10.3 & 9.3 & 8.7 & 10.1 & 12.4 & 6.0 \\
Kosova & 18.3 & 17.7 & 81.0 & -32.0 & -0.3 & 42.6 & 61.9 & -35.5 & 8.6 & -10.9 & 20.3 & 15.6 \\
Sirbistan & 10.1 & 17.4 & 4.1 & 0.5 & 13.4 & 2.7 & 2.9 & -3.7 & 8.4 & -5.1 & -0.6 & 4.4 \\
Makedonya & 21.9 & 15.8 & 7.9 & 3.9 & 9.2 & 4.1 & -3.8 & 25.9 & -1.1 & 14.1 & 0.6 & 8.7 \\
Türkiye & 9.0 & 27.7 & 0.9 & 22.5 & 39.1 & 29.8 & 38.6 & 12.5 & 18.8 & 15.7 & 12.1 & 20.1 \\
\hline
\end{tabular}

Kaynak: IMF, Dünya Bankas1, https://unctadstat.unctad.org 
Yukarıda Tablo 6'dan da görüleceği gibi, Türkiye ve Balkan ülkelerinin ylllı kredi verilerinden yararlanılarak hesaplanan kredi büyüme yüzdeleri, 2007-2017 döneminde inişli çıkışlı bir seyir izlemiştir. İncelenen dönemde en düşük değerler \% 3,8 ile Yunanistan, \% 4,4 ile Surbistan ve \%6,0 ile Bosna'da, en yüksek değerler ise \%20,1 ile Türkiye, \% 15,6 Kosova ve \%13,6 ile Karadağ’da gözlemlenmiştir.

\section{Özel Sektöre Verilen Yurtiçi Kredilerin/ GSYH Oranı}

Finansal kırılganlığın bir başka göstergesi de özel sektöre verilen yurtiçi kredilerin GSYH’ye oranıdır.

2007-2017 döneminde bankaların özel sektöre kullandırdığ1 yurt içi kredilerin GSYH oranı aşağıda Tablo 7'de verilmiştir. Özel sektöre yurtiçi kredilerin genişlemesi, borçlanan kesimin herhangi bir şok veya krizde borçlarını ödeyememe riskini yükseltmekte ve bunun sonucunda da ülkelerin kırılganlığı artmaktadır (Karakurt vd., 2015, s. 302).

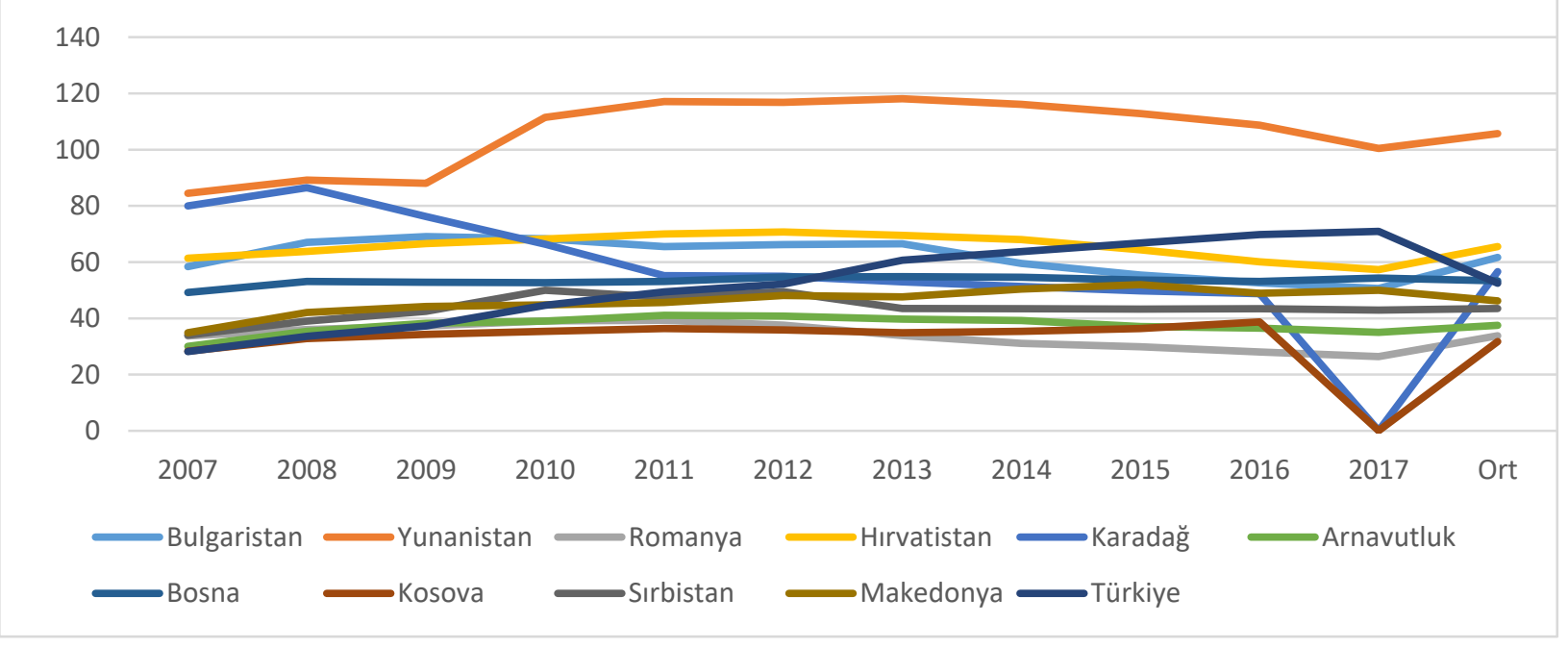

Şekil 6. Özel Sektöre Yurtiçi Kredilerin GSYH'ye Oranndaki Değğsme (\%)

Tablo 7. Özel Sektöre Yurtiçi Kredilerin GSYH'ye Oranmdaki Değissme (\%)

\begin{tabular}{lllllllllllll}
\hline Ülke/Y11 & $\mathbf{2 0 0 7}$ & $\mathbf{2 0 0 8}$ & $\mathbf{2 0 0 9}$ & $\mathbf{2 0 1 0}$ & $\mathbf{2 0 1 1}$ & $\mathbf{2 0 1 2}$ & $\mathbf{2 0 1 3}$ & $\mathbf{2 0 1 4}$ & $\mathbf{2 0 1 5}$ & $\mathbf{2 0 1 6}$ & $\mathbf{2 0 1 7}$ & Ort \\
\hline Bulgaristan & 58.4 & 67.0 & 69.1 & 68.3 & 65.5 & 66.2 & 66.5 & 59.5 & 55.4 & 52.6 & 50.6 & 61.7 \\
Yunanistan & 84.5 & 89.2 & 88.0 & 111.5 & 117.1 & 116.8 & 118.1 & 116.1 & 112.8 & 108.7 & 100.4 & 105.7 \\
Romanya & 33.7 & 36.0 & 37.3 & 39.1 & 39.3 & 37.6 & 33.9 & 31.1 & 29.9 & 28.0 & 26.4 & 33.8 \\
Hirvatistan & 61.4 & 63.8 & 66.6 & 68.2 & 70.0 & 70.7 & 69.5 & 68.0 & 64.4 & 60.1 & 57.3 & 65.5 \\
Karadağ & 80.0 & 86.5 & 76.2 & 66.4 & 55.2 & 55.0 & 53.0 & 51.3 & 49.8 & 48.8 & - & 56.6 \\
Arnavutluk & 30.0 & 35.4 & 38.2 & 39.0 & 41.1 & 40.8 & 39.7 & 39.2 & 37.1 & 36.5 & 35.0 & 37.5 \\
Bosna & 49.2 & 53.1 & 52.8 & 52.7 & 53.1 & 54.7 & 54.8 & 54.6 & 53.6 & 53.1 & 54.3 & 53.3 \\
Kosova & 28.3 & 32.8 & 34.3 & 35.4 & 36.4 & 35.9 & 34.9 & 35.4 & 36.4 & 38.7 & - & 31.7 \\
Sirbistan & 34.0 & 39.0 & 42.5 & 50.0 & 47.5 & 49.5 & 43.5 & 43.4 & 43.3 & 43.4 & 42.9 & 43.5 \\
Makedonya & 34.9 & 42.1 & 44.2 & 44.8 & 45.6 & 48.1 & 47.6 & 50.4 & 52.0 & 48.9 & 50.0 & 46.2 \\
Türkiye & 28.2 & 33.6 & 37.3 & 44.6 & 49.4 & 52.2 & 60.7 & 63.7 & 66.8 & 69.8 & 70.9 & 52.5 \\
\hline
\end{tabular}

Kaynak: IMF, Dünya Bankas1, https://unctadstat.unctad.org

2017 yllı itibarıyla Yunanistan, \%100,4’lük yurtiçi kredi büyümesi oranı ile incelenen ülkeler içerisinde en kırılgan ülkedir. Yunanistan'1 \% 70,9 ile Türkiye ve \%57,3 ile Hirvatistan takip etmektedir. Diğer taraftan 2007-2017 dönemi ortalamasına göre yurtiçi kredi büyümesinde en kır1lgan ülke \%105,7 ile Yunanistan'dır. Bu ülkeyi \%65,5 ile Hırvatistan ve \%61,7 ile Bulgaristan izlemektedir. En az kırllgan ülkeler ise \%31.71 ile Kosova ilk sırada yer alırken bu ülkeyi \%33,8 ile Romanya ve \%37,5 ile Arnavutluk takip etmektedir.

\section{Tartışma, Sonuç ve Öneriler}

Küreselleşmeyle birlikte artmaya başlayan dışa bağımlılık ve spekülatif sermaye akımlarının yanı sıra, düşük yurtiçi tasarruf oranı, cari açılar ve yoğun siyasi belirsizlikler Balkan ülkeleri ve Türkiye'de makroekonomik kırılganlı̆ı artırmıştır. Yükselen makroekonomik kırılganlık bölge ülkelerinin büyüme ve rekabet gücünü azaltmış, kurlarda dalgalanmalara ve buna bağlı olarak doğrudan yabancı sermaye yatırımlarının gerilemesine, dış ticaret hacminin daralmasına ve enflasyonun artmasına neden olmuştur. 
Çalışmada makroekonomik kırılganlığı analiz etmek için altı kırılganlık göstergesi, balkan ülkeleri ve Türkiye açısından değerlendirilmiştir. 2007-2017 döneminde ortalama bütçe dengesinin GSYH'ye oran1, başta Yunanistan olmak üzere Hirvatistan, Karadağ ve Arnavutluk için risk oluşturmaktadır. Türkiye'nin bu ülkelere göre daha düşük oranlı bütçe açığına sahip olması risk algisının azaldı̆̆ını ve sık1 maliye politikasının başarısını göstermektedir.

Kamu borcunun GSYH'ye oranında ise Yunanistan, Hirvatistan ve Arnavutluk, kamu borcu yüksekliğinin kırılganlık meydana getirdiği ülkeler olarak görülmüştür. Türkiye ise Bulgaristan, Romanya, Makedonya gibi kamu borcunun GSYH'ye oranı \%40’ın altında olan dolayısıyla kırılganlık riski düşük olan ülkelerdir.

2007-2017 dönemine ilişkin ortalamalara göre en yüksek cari işlemler açığ1/GSYH oranına sahip, dolayısıyla da kırılganlık sinyali veren ülke Karadağ'dır. Bu ülkeyi Kosova ve Arnavutluk takip etmektedir. Döviz rezervleri cari işlemler açı̆̆ını kapatmada kullanıldığından döviz rezervlerinin GSYH’ye oranı önemli kırılganlık göstergelerinden biri haline gelmektedir. Döviz rezervinin GSYH'ye oranı Bulgaristan, Sırbistan ve Bosna için diğer bölge ülkelerine göre daha az kırılganlık oluşturacak düzeydedir. Bununla birlikte başta Yunanistan olmak üzere Türkiye, Kosova ve Karadağ'da rezervler diğer bölge ülkeleri ile kıyaslandığında oldukça düşük düzeydedir.

Son olarak, 2007-2017 döneminde bankaların özel sektöre kullandırdığ1 yurt içi kredilerin GSYH’ye oranındaki değişim açısından, dönem ortalamasına göre en kırılgan ülke Yunanistan'dır. Bu ülkeyi Hirvatistan, Bulgaristan, Bosna ve Türkiye izlemektedir. En az kırllgan ülkeler ise Kosova, Romanya ve Arnavutluk'tur.

Çalışmada balkan ülkelerinin her biri ve Türkiye için, farklı kırılganlık göstergelerinin tehlike oluşturduğu ve bazı ülkelerde birden fazla kır1lganlık göstergesinin öne çıktı̆̆1 görülmüştür. Yunanistan, Türkiye, Hirvatistan ve Karadağ bölge ülkeleri içerisinde en çok makroekonomik göstergede alarm veren, risk primi yüksek dolayısıyla makroekonomik kırılganlı̆̆1 yüksek piyasalar olarak görünmektedir. İki ya da daha fazla göstergesi olumsuz olan bu ülkelerin sahip oldukları farklı kırılganlık göstergeleri dikkate alınarak, kırılganlı̆̆ın giderilmesine yönelik politikalar uygulanmak suretiyle ekonominin direncinin arttırılması amaçlanmalıdır. Belirtilen bu altı gösterge göz önüne alındığında cari denge/GSYH, kamu borcu/GSYH ve bütçe dengesi/GSYH bakımından bölge içerisinde kırılganlığı daha az olan ülkeler arasında bulunan Türkiye, istikrarlı ekonomik büyüme ve daha yüksek refah seviyesi için kırılganlık riski oluşturan döviz rezervi/GSYH ve yurt içi kredilerin/ GSYH göstergelerini düzetmeye yönelik makroekonomik politikalar uygulaması, yapısal reformlarla yurtiçi tasarrufların artırılması ve böylece ekonominin iç ve dış şoklara karşı daha dirençli hale getirilmesi önem arz etmektedir.

\section{Etik Beyan}

"Makroekonomike Kırlganlı̆̆n Ölçülmesi: Balkan Ülkeleri ve Türkiye İçin Karşılaştırmalı Bir Analiz” başlıklı çalışmanın yazım sürecinde bilimsel, etik ve alıntı kurallarına uyulmuş; toplanan veriler üzerinde herhangi bir tahrifat yapılmamış ve bu çalışma herhangi başka bir akademik yayın ortamına değerlendirme için gönderilmemiştir.

\section{Kaynakça}

Adger, W. N. (2006). Vulnerability. Global Environmental Change, 16(3), 268-281.

Akın, F. (2017). Türkiye ve seçilmiş balkan ülkelerinde makroekonomik kırılganlık: Karşılaştırmalı bir analiz. Balkan ve Yakin Doğu Sosyal Bilimler Dergisi, 4(3), 88-96.

Andrews, C. ve Flores, M. (2008). Improving food crisis responses in fragile states. UNUWIDER Research Paper, 42 , $1-16$.

Bayrak, M. ve Esen, Ö. (2012). Bütçe açıklarının cari işlemler dengesi üzerine etkileri: İkiz açılar hipotezinin Türkiye açısından değerlendirilmesi. Ekonomik Yaklașım, 3(82), 23-49.

Bayraktar, Y. ve Elüstü, S. (2016). Makroekonomik kırılganlığın ölçülmesi: Yükselen piyasalar ve Türkiye için karşılaştırmalı bir analiz. Uluslararası Emek ve Toplum Dergisi, 5(11), 9-29.

Boğa, S. (2017). Finansal kırılganlıklar ve uluslararası sermaye hareketleri: Gelişmekte olan ülkeler üzerine bir analiz. Finansal Arastirmalar ve Calismalar Dergisi, 9(16), 1-17.

Briguglio, L. ve Galea, W. (2003). Updating and augmenting the economic vulnerability https://secure.um.edu.mt/_data/assets/pdf_file/0012/44130/eviar_briguglio_galea_ver4.pdf,

Briguglio, L., Cordina, G., Farragia, N. ve Vella, S. (2009). Economic vulnarability and resilience: Concepts and measurement. Oxford Development Studies, 37(3), 229-247. 
Chaudri, S., Jalan, J. ve Suryahadi, A. (2002). Assessing household vulnerability to poverty from cross-sectional data: A methodology and estimates from Indonesia. Columbia University Department of Economics Discussion Paper Series, $52,1-25$.

Çan, H. ve Dinçsoy, M. O. (2016). Kırılganlık göstergeleri ve kırılgan beşli ülkeleri üzerine bir inceleme. Akademik Sosyal Arastırmalar Dergisi, 4(22), 199-217.

Doğantan, E ve Kozak, M.A. (2018). Turizm işletmelerinde kırılganlıklar: karşılaştırmalı bir analiz. Seyahat ve Otel İsletmeciliüi Dergisi, 15(3), 581-589.

Eleren, A ve Karagül, M. (2008). 1986-2006 Türkiye ekonomisinin performans değerlendirmesi. Celal Bayar Üniversitesi İİ.B.F. Yönetin ve Ekonomi, 15(1), 1-14.

Guillaumont, P. (1999). On the Economic Vulnerability of Low Income Countries, http://siteresources.worldbank.org/INTPOVERTY/Resources/WDR/stiglitz/Guillau2.pdf.

Guillaumont, P. (2008). An economic vulnerability index: Its design and use for international development policy. UNU-WIDER Research Paper, 99, 1-32.

Güngör, K. (2016). Küresel ekonomik kriz sürecinde aday ülkelerin mali performanslarının Avrupa Birliği'ne üyelik kriterlerine uyumu. Business \& Management Studies: An International Journal, 4(3), 273-290.

Karakurt, B., Şentürk, S. H. ve Ela, M. (2015). Makro ekonomik kırılganlık: Türkiye ve Şangay beşlisi karşılaştırması. Yönetim ve Ekonomi Arastırmalar Dergisi, 13(1), 283-307.

Mete, M., Pekmez, G ve Kıyançiçek, C. (2016). 2008 finans krizinin kırılgan sekizliler üzerindeki etkisi: Teorik bir inceleme. Elektronik Sosyal Bilimler Dergisi, 15(57), 689-709.

Moody's (2014). External vulnerabilities, exposures, mitigants and credit supports. Moody's Investors Service Special Comment, https://www.moodys.com/research/Emerging-MarketSovereign-Research-Series-ExternalVulnerabilities-Exposures-Mitigants-and--PBC_165831. Erişim Tarihi (02-03-2019)

Özyıldız, H. (2014). Kırllganlık göstergeleri. http://www.hakanozyildiz.com/2014/02/krlganlk-gostergeleri.html, (18.02.2019).

Seth, A. ve Ragab, A. (2012). Macroeconomic vulnerability in developing countries: Approaches and 1ssues. International Policy Centre for Inclusive Growth Working Paper, 94, 1-22.

Rubia, O., Roldan, C. ve Esteve, V. (2006). Is the budget deficit sustainable when fiscal policy is non-liner? The case study of Spain. Journal of Macroeconomics, 1(28), 596-608.

T.C. Sofya Ticaret Müşavirliği Bulgaristan'ın Genel Ekonomik Durumu ve Türkiye ile Ekonomik - Ticari İlişkileri (2017-2018), Ağustos 2018, Sofya:1-155.

TCMB. (2005). Türkiye Cumhuriyet Merkez Bankası'nda Döviz Rezervi Yönetimi, http://www.tcmb.gov.tr/wps/wcm/connect/190faaac-0065-48a4-8550-cfdd698abf02/Doviz-RezervYonetimi.pdf?MOD=AJPERES.

Tokucu, E. (2012). Hyman Minsky'nin Finansal Đstikrarsızlık Hipotezi Çerçevesinde Finansal Krizler Ve Çözüm Öneriler. Ankara Üniversitesi SBF Dergisi, 67(2), 189-212.

T.C. D1ş İşleri Bakanlı̆̆1 2018 http://www.mfa.gov.tr/arnavutluk-ekonomisi.tr.mfa

T.C. Ticaret Bakanlığ1 (www.ticaret.gov.tr).

T.C. Ticaret Bakanlığ1 Sofya Ticaret Müşavirliği, 2018

https://unctadstat.unctad.org

https://www.imf.org/external

https://unctadstat.unctad.org

https://data.worldbank.org

https://tradingeconomics.com

\section{EXTENDED ABSTRACT}

In the economic report of Morgan Stanley (2013), the macroeconomic fragility used by the investment bank to identify the countries with the most fragile structure against the global capital flows ("Fragile Five") in the light of the current account deficit/GDP ratio, the problems that cause instability by increasing risk and uncertainty in national economies, negatively reflects the macroeconomic indicators of the countries from the developments in domestic and foreign conjuncture. Macroeconomic fragility, which makes all countries' economies vulnerable to internal and external shocks and creates crisis-prone structures, has come to the forefront due to recent risks and instability in the world economy and has been the subject of many studies.

The Balkan countries included in the study are Bulgaria, Bosnia and Herzegovina, Montenegro, Albania, Croatia, Greece, Kosovo, Romania, Macedonia and Serbia. For 2017 the highest GDP in the region belongs to Turkey with 851 billion dollars, Romania follows it with 212 billion dollars and Greece is the third with 200 billion dollars. Four of the Balkan countries (Bulgaria-Romania-Croatia-Greece), are members of the European Union, and Bosnia and Herzegovina, Montenegro, Albania, Kosovo, Macedonia and Serbia are candidate countries like Turkey. 
Apart from other studies, in this study Turkey and other Balkan countries are compared in terms of macroeconomic fragility. Since the early 1990s, Balkan countries (except for Turkey and Greece) had implemented the centre and the planned economic system, rather than outward-oriented development model in the region. Until the mid-1990s, the region largely influenced by war and political instability by political instability, and they came across major macroeconomic problems such as high inflation, the unemployment, per capita and the low rate national income.

In recent years, although they have achieved positive developments in reducing inflation, a large proportion of unemployment remains a major problem. On the other hand, the Balkan countries that have transitioned to liberal economic policies since the early 1990s, in spite of the gains from these policies, they have become vulnerable to internal and external shocks and speculations due to imbalances in the current account balance and deteriorating budget balance. That is why the indicators pointing to fragility are important to understand the fields where economies are weak, whether they are prone to crisis, or to understand the level of exposure to an external crisis.

In the analysis, to measure macroeconomic fragility, six basic variables were used as financial fragility (budget balance/GDP, public debt/GDP), financial fragility (GDP to private sector loans, annual loan growth rates) and external fragility (current balance/GDP, foreign exchange reserve/GDP). In this comparison, while in Turkish economy the elements lead to fragility are determined as current account balance/GDP, annual loan growth rate and foreign exchange reserve/GDP; on the other hand, foreign exchange reserve/GDP, budget balance/GDP and public debt/GDP for Bulgaria; and budget balance/ GDP, and domestic credit growth for Kosovo are the least elements cause fragility. Greece is the most vulnerable country among the countries analysed with the current account balance/GDP, foreign exchange reserve/GDP, budget balance/GDP, public debt/GDP and domestic credit growth. 